\author{
W. Julian KORAB-KARPOWICZ \\ Uczelnia Łazarskiego w Warszawie \\ Uniwersytet Zayed w Dubaju \\ wjkk@trinity-oxford.org
}

\title{
NOWA POLITYKA
}

\section{WPROWADZENIE DO EWOLUCYJNOŚCI}

\section{ABSTRACT On the New Politics: An Introduction to Evolutionity}

This article introduces a vision of the new politics that emerges from my recent book Tractatus Politico-Philosophicus. The Tractatus discusses a number of topics. To name just a few, these are: politics, human nature, the state, freedom, solidarity, democracy, civilization, family and marriage, power, international relations, war and peace. Also, it introduces new words, such as sophocracy, ennobled democracy; nativeculturalism (an alternative to multiculturalism); or parentsexuality, a privileged form of sexuality. It addresses many issues that concern today's political thinkers. The main objective of my work is to demonstrate the necessity of, and provide a guide for, the redirection of humanity. The piece argues that this paradigm shift must involve changing the character of social life and politics from competitive to cooperative, encouraging moral and intellectual virtues, providing foundations for happy societies, promoting peace among countries and building a strong international community. The article attempts to show that the essence of politics is not a struggle for power, which can only be its derivative meaning, but rather the ability to organize society for cooperation and actualize a good life. It also reminds humanity of its high task, which is moral and intellectual perfection, and advancing human evolution.

Keywords: political philosophy, modernity, evolutionity, classical tradition, individualism

Słowa kluczowe: filozofia polityczna, moderność, ewolucyjność, tradycja klasyczna, indywidualizm 
Wowa polityka, którą przedstawiam w Traktacie polityczno-filozoficznym ${ }^{1}$, to sztu- $^{-}$ 1 ka rządzenia, to $w$ istocie organizacja spoteczeństwa dla wspótdziatania (1), służąca całemu społeczeństwu. Opiera się na zrozumieniu, kim jest człowiek i jaka jest rola ludzi w procesie ewolucji. To polityka właściwa, albo właściwie rozumiana, która umieszcza życie ludzkie w kontekście istnienia całego wszechświata, realizuje dobro wspólne całej społeczności oraz umożliwia pełny rozwój człowieka. Jej celem jest życie dobre albo wszechstronny dobrobyt obywateli, umożliwiający ich samorealizację. $\mathrm{Na}$ poziomie międzynarodowym służy ona pokojowemu rozwiązywaniu konfliktów oraz budowaniu silnej społeczności międzynarodowej. Wraz z nową polityką rozpoczyna się nowa epoka w historii ludzkości.

Polityka jest też często rozumiana jako walka o władzę albo o potęgę². Jest to polityka wadliwa, która nie służy społeczności ani nie realizuje dobra wspólnego, a jedynie dobro partykularne, jakim jest korzyść określonej jednostki lub grupy. W przypadku polityki rozumianej jako walka o potęgę jednostki, partie polityczne, grupy politycznego nacisku, elity władzy lub inni aktorzy na scenie politycznej chcą zdobyć władzę dla siebie. Jej celem nie jest dobro wspólne i wspólna wolność, służąca wszystkim, ale osiągnięcie panowania i podporządkowanie sobie innych ludzi dla własnej partykularnej korzyści. Polityka rozumiana jako walka o władzę jest moralnie uzasadniona jedynie w przypadku, kiedy panowanie jednych ludzi nad drugimi nie jest celem samym w sobie, ale jedynie środkiem do celu, jakim jest zaprowadzenia dobrych rządów, czyli takich, które służą całej społeczności i realizują dobro wspólne.

Równie wadliwa jest polityka rozumiana jako biznes, mająca na celu zysk, który często połączony też jest z kontrolą i ukrytym panowaniem. W mikroskali taka polityka przejawia się w korupcji urzędniczej, a więc wykorzystywaniu funkcji publicznych dla osobistego wzbogacenia. Osoba skorumpowana, motywowana własną korzyścią, działa na szkodę swojej społeczności, doprowadzając do niekorzystnych dla niej transakcji gospodarczych czy finansowych. Nieporównywalnie większą szkodę wyrządza jednak polityka jako biznes w makroskali. Jej skutkiem są rewolucje i wojny. Traktuje ona politykę jako grę, w której nagrodą są zysk i dominacja oparta na zdobytej

W.J. Korab-Karpowicz, Tractatus politico-philosophicus. Traktat polityczno-filozoficzny, Kęty 2015, Biblioteka Europejska. Dalsze numerowane cytaty pochodzą z tej samej pracy. W niektórych miejscach numeracja cytatów została zmieniona zgodnie z najnowszym wydaniem Traktatu w języku angielskim. Zob. W.J. Korab-Karpowicz, Tractatus Politico-Philosophicus. New Directions for the Future Development of Humankind, New York 2017, Routledge Focus.

2 Uważany za jednego z twórców dwudziestowiecznego realizmu politycznego Hans Morgenthau podkreślat, że international politics, like all politics, is a struggle for power [„polityka międzynarodowa, jak każda polityka, jest walką o potęgę"]. Dla wielu politologów z kręgu języka angielskiego pozostających pod wpływem myśli Morgenthaua „power” jest najważniejszym pojęciem politycznym. Na język polski „power” przetłumaczyć można za pomocą takich wyrazów, jak: „moc”, „potęga”, „panowanie”, „władza”. Żaden z nich nie oddaje jednak w pełni jego znaczenia. Sens wyrażenia angielskiego struggle for power można w przybliżeniu oddać słowami „walka o władzę, potęgę, moc”. Zob. H. Morgenthau, Politics among Nations. The Struggle for Power and Peace, wyd. 2, New York 1956, s. 25; w thumaczeniu polskim: Polityka między narodami. Walka o potegę i pokój, przejrzał i uzup. K.W. Thompson, przeł. R. Włoch, Warszawa 2010, s. 47. 
fortunie. O ile w języku codziennym wyrażamy nasze aspiracje do pozytywnych zmian politycznych, posługując się takimi pojęciami, jak: „wolność”, „równość”, „sprawiedliwość”, „demokracja”, „godność człowieka”, dla biznesowych graczy politycznych w skali makro są to puste słowa, które mają jedynie znaczenie instrumentalne. Wykorzystuje się je do gry. W polityce rozumianej jako biznes liczy się zysk finansowy, jaki osiąga się dzięki pożądanym zmianom, a w przypadku konfliktów zbrojnych także dzięki handlowi bronią. Wojny i zmiany rewolucyjne otwierają rynki zbytu i są zawsze związane z nowymi możliwościami dla biznesu. Konflikty zbrojne utrzymują przemysł zbrojeniowy i przynoszą dochody. W polityce globalnej rozumianej jako biznes o nic więcej poza pieniądzem oraz wynikającą z pieniądza coraz większą kontrolą nad innymi ludźmi nie chodzi. Jej hasło to: „Uczyń z polityki intratny interes i spowoduj, aby ludzie wykonali pracę dla ciebie"3. Zaangażowani w nią aktorzy finansują grupy opozycyjne wobec władz państwowych realizujące ich plan, wykorzystują i stymulują nastroje społeczne, używając sloganów, takich jak „demokracja i wolność" dla wywoływanie pożądanych zmian. Efektem ich działalności jest wzbogacenie się nowych elit, ale zazwyczaj nie społeczeństwa.

Oligarchia globalna, czyli elita kapitału, dla której polityka to biznes w skali makro, pozostaje zazwyczaj w ukryciu. Trafnie ujął ten fakt prof. Lamentowicz: żyjemy $\mathrm{w}$ panoptykonie, czyli w przestrzeni totalnie przezroczystej, gdzie wszyscy wszystko wi$d z q$ z waznym wyjatkiem, bo nie widza tego, kto panuje nad systemem $i$ zniewala przez manipulacje ideami wolności, a nie przez twarde nakazy i zakazy. Taka strategia stabilizacji [gry] politycznej jest bardziej skuteczna niż opresyjne i represyjne strategie rzaddzenia stosowane dawniej na Zachodzie... Anonimowość panowania oligarchii taczy się z coraz bardziej intensywna konkurencją między jednostkami, która niszczy solidarność oraz kolektywnq energiępolityczna pracowników najemnych ${ }^{4}$. W wyrafinowanych metodach rządzenia, nie bezpośrednio, ale za pomocą umiejętnej manipulacji medialnej, wpływów na nastroje społeczne i popierania wybranych przez siebie ludzi i grup, współczesna oligarchia globalna znacznie udoskonaliła nauki Machiavellego, ale jednocześnie odeszła od jego przesłania moralnego - służenia wspólnocie. Dla autora Księcia wzniosły cel, jakim była wolna republika, uświęcał haniebne środki. Jednakże w przypadku dzisiejszej ukrytej oligarchii zarówno cel, jak i środki wydają się haniebne. Celem jest pieniądz, który stanowi korzyść jedynie dla niewielkiego kręgu ludzi bardzo bogatych i daje im możliwości coraz większej kontroli i manipulacji społeczeństwami sloganami demokracji i wolności oraz wywołania kolejnego kryzysu lub konfliktu zbrojnego przynoszącego następny pieniądz.

Polityka rozumiana jako walka o władzę i jako biznes nie prowadzi ludzkości do szczęścia. Polityki nie da się oddzielić od etyki. Szczęśliwą społeczność i harmonię społeczną, czy to na poziomie państwa, czy też w skali międzynarodowej, można zbudować

\footnotetext{
Podstawowa reguła polityki traktowanej jako biznes została przedstawiona w 1906 r. przez Frederica Howe'a w książce The Confessions of the Monopolist. W angielskim oryginale brzmi ona następująco: First, let society work for you; and second, make a business of politics.

4 W. Lamentowicz, Strategia państwa. Teoria państwa aktywnego wobec sit spontanicznych, Warszawa 2015, s. 64.
} 
jedynie na podstawach moralnych. To iluzja, że człowiek, nawet najbogatszy, może być szczęśliwy, oddzielając politykę od moralności i swoje działania od wyższych celów w życiu. Jak pisał Wincenty Lutosławski, który słusznie ujmował politykę w szerszej perspektywie egzystencji człowieka: życie ludzkie na Ziemi jest drobną cząstką rzeczywistości wszechświata. Bez ogarnięcia całości, bez sięgania do źródła [naszego] bytu niepodobna zrozumieć znaczenia globu ziemskiego i jego mieszkańców ${ }^{5}$. Pieniądz, choć dający nam utrzymanie i możliwości działania, to tylko jedna z wartości, jaką można związać ze spełnionym życiem. Jest rzeczą oczywistą, że potrzebujemy stabilnych podstaw materialnych dla naszego rozwoju jako jednostki i społeczeństwa, podobnie jak potrzebujemy bezpieczeństwa, sprawiedliwości, solidarności i wolności. Nie są to puste hasła, a dobra, z jakich składa się życie dobre. O ile polityka jako sztuka rządzenia je realizuje i służy całemu społeczeństwu, a ludzkości do rozwoju, o tyle jest to polityka właściwa. O ile realizuje je określone państwo, które jako obrońca i organizator społeczeństwa stwarza obywatelom warunki do samorealizacji, uwzględniając ich indywidualne preferencje, a jednocześnie wymogi wspólnego dobra, o tyle jest to państwo dobre, którego powinniśmy zacięcie bronić.

Dobrego państwa, którego siła opiera się na mądrości jego przywódców i cnotach jego obywateli, nie zastąpi sztuczny twór - efekt wyreżyserowanej integracji, który z uwagi na swoją centralizację i deficyt demokracji ${ }^{6}$ daje łatwiejsze pole działania globalnej oligarchii. Nie są więc dobrymi rozwiązaniami będąca dziś w poważnym kryzysie Unia Europejska ani planowane w kuluarach wielkiej polityki państwo światowe. Nauka współczesna, a szczególnie teoria kwantów pokazuje, że podstawą rzeczywistości nie są układy scentralizowane, lecz te, w których zjawiska pojawiają się w sieci wzajemnych interakcji. Współdziałanie między podmiotami i ich interakcje wyraża się w sposób naturalny w formie ich wspólnoty. Może więc i powinna istnieć silna wspólnota międzynarodowa złożona z suwerennych państw, które łączą wspólnie wypracowane normy społeczne oraz wspólne wartości dążenia do dobrobytu, rozwoju, pokoju i wolności. Może też w Europie istnieć i doskonale funkcjonować Wspólnota Europejska, oparta na interesach gospodarczych państw członkowskich, poszanowaniu ich integralności kulturowej, wspólnym dążeniu do współpracy i rozwijania się w pokoju; stymulująca innowacyjność i wymianę naukowo-techniczną, ale wystrzegająca się nadmiernej biurokracji i daleko posuniętej integracji. Do tej formuły, współgrających ze sobą państw narodowych połączonych wolą współpracy i pokoju oraz wspólnym dziedzictwem cywilizacyjnym Europy, powinna wrócić Unia, a nie dążyć do pogłębiania struktur integracyjnych, narzucania arbitralnej woli swym członkom, osłabiania ich kultur narodowych i pozbawiania ich suwerenności.

Filozofia moderności opiera się na konstrukcji teoretycznej, jaką jest umowa społeczna, którą zawierają między sobą abstrakcyjne, pozbawione konkretnego miejsca i czasu jednostki, poruszane przez pożądania, aby zawiązać społeczeństwo i utworzyć

W. Lutosławski, Praca narodowa, Warszawa 1998, s. 88, Mata Klasyka Filozofii.

6 W przypadku Unii Europejskiej mianem deficytu demokracji określa się sytuację braku reprezentatywności i legitymacji instytucji unijnych. Zob. J. Czaputowicz, Suwerenność, Warszawa 2013, s. 387. 
państwo ${ }^{7}$. Pragnienie bezpieczeństwa w obliczu narastającego konfliktu prowadzi je do zawarcia kontraktu i do zgody, aby żyć we wspólnocie pod władzą suwerena ${ }^{8}$. Jednakże, w przeciwieństwie do tych abstrakcyjnych, wyimaginowanych jednostek, ludzie są w rzeczywistości zawsze członkami mniejszej lub większej społeczności, której najbardziej podstawowym elementem składowym jest rodzina. Bez tej społeczności człowiek nie mógłby się urodzić, wychować, rozwinąć swoich zdolności i umarłby szybko śmiercią naturalną. Związek z określoną społecznością i współdziałanie w jej ramach jest więc nieodłączną, naturalną treścią każdego indywidualnego ludzkiego życia. Co najwyżej jednostka może zmienić kraj swojego pobytu i zastąpić jedną społeczność drugą.

Człowiek jest z natury istotą społeczną. Ma naturalną dyspozycję do życia w społeczeństwie, współdziałania z innymi i czerpania korzyści z życia społecznego. Jednostka jako samodzielny byt to fikcja.

Współdziałanie to inaczej zgodna współpraca między ludźmi; to wzajemna wymiana usług, odwzajemnione działanie na rzecz kogoś innego. Tym innym może być ktoś, z kim mamy kontakt bezpośredni, albo - w przypadku współpracy w ramach społeczeństwa lub większych grup - osoby, których nie znamy. Odwzajemnienie może mieć formę wynikającą z umowy lub nie wiązać się z żadną umową, a jedynie z oczekiwaniem od innych określonych działań lub zachowań. Współdziałanie, pierwsza zasada ludzkości (10.11), prowadzi ludzi do samorealizacji, państwa do dobrobytu, a społeczność międzynarodową do pokoju. Wraz z nową polityką, której istotą jest współdziałanie, rozpoczyna się nowa epoka w historii ludzkości. Jest to epoka ewolucyjna, ewolucyjność, która zastępuje moderność i postmoderność.

Moderność podkreśla racjonalizm i rozwój naukowy. Powstanie tej formacji ideowej było zainspirowane mechanistycznym, materialistycznym i deterministycznym obrazem świata wyłaniającym się na progu moderności z nauki nowożytnej’.

Według Hobbesa wszyscy ludzie są jednakowo pobudzani, a raczej pobudzani przez pożądania (passions), zwłaszcza przez state i nieznające spoczynku pragnienie coraz to większej mocy, które ustaje dopiero ześmiercia (L XI 2). To na skutek takich pożądań, jak pragnienie zysku, własnego bezpieczeństwa czy też sławy, ludzie próbują się wzajemnie zniszczyć lub sobie podporządkować i znajdują się w stanie wojny. Na skutek strachu przed śmiercią i chęci jej uniknięcia decydują się na pokój. Zob. T. Hobbes, Lewiatan czyli Materia, forma i wtadza państwa kościelnego i świeckiego, przeł. Cz. Znamierowski, wstęp J.C.A. Gaskin, Warszawa 2005.

8 Główną tezą kontraktualizmu, który narodził się u progu moderności, jest koncepcja umowy społecznej, czyli procedury, w której wyniku następuje przejście ze stanu natury do społeczeństwa i państwa. U podstaw umowy albo kontraktu społecznego, w wersji przedstawionej przez Thomasa Hobbesa i Johna Locke’a, leżą dogmatyczne założenia dotyczące m.in. domniemanego stanu natury, w jakim znajdują się jednostki przed umownym zawiązaniem się społeczeństwa, oraz egoistycznej i konfliktogennej natury człowieka. Jest to część ideologii, jaką powiązać można z dzisiejszą, modernistyczną cywilizacją Zachodu. Umowa społeczna pełni w niej funkcję wyjaśniającą, a zarazem legitymizującą. Wyjaśnia genezę społeczeństwa oraz państwa. Usprawiedliwia władzę, własność oraz określone formy rządów (w szczególności demokrację). W wersji, jaką nadał jej John Rawls, służy do zdefiniowania sprawiedliwości i określenia podstaw sprawiedliwego społeczeństwa. Zob. W.J. Korab-Karpowicz, Umowa czy harmonia spoteczna, „Societas et Ius” 2015, nr 4, s. 8-18, [online] http://dx.doi.org/10.12775/SEI.2015.001.

9 Dla przypomnienia, w moim rozumieniu nowożytność to nie tylko pewien okres historyczny, epoka 
Postmoderność, efekt procesów globalizacyjnych i myśli postmodernistycznej, charakteryzuje się z kolei niepokojącym regresem do nieracjonalności, a w konsekwencji wielką niestabilnością polityczną oraz wieloma nierozwiązanymi problemami związanymi z globalizacją. Inspiracją dla nowej formacji ideowej, a zarazem nowej epoki, jaką jest ewolucyjność, jest koncepcja ludzkiej ewolucji oraz holistyczny obraz świata, jaki wyłania się z nauki współczesnej. Jako formacja ideowa nie ma ona charakteru rewolucyjnego, charakterystycznego dla modernistycznych i postmodernistycznych koncepcji intelektualnych i politycznych, ale ewolucyjny. Nie występuje przeciwko tradycji i religii, ale raczej docenia ich wartość i stara się na nich oprzeć. Jej szczególną cechą jest to, że powraca do tradycji klasycznej i klasycznej racjonalności. Racjonalność klasyczna, która w swej istocie jest ewolucyjna, polega na myśleniu i mówieniu z sensem na temat wartości. W polityce wyraża się ona w pragmatyzmie dziatań, mających na celu życie dobre (9.216). Życiem dobre, dobrobyt obywateli, umożliwia ich spełnione życie, czyli samorealizację.

Szczęście to nie jest tylko chwila przyjemności. Nie sprowadza się ono do zaspokajania niekończących się pożądań. W pełnym tego słowa znaczeniu „szczęście” oznacza spełnione życie, samorealizację, najwyższe dobro, jakiego zazwyczaj pragną ludzie. Uznanie szczęścia za normatywny, najwyższy cel społeczeństwa jest starą tradycją nawiązującą do Arystotelesa, który w Etyce nikomachejskiej pisał: Do szczę́cia bowiem dążymy zawsze dla niego samego, a nigdy dla czegoś innego ${ }^{10}$. Nowa polityka nie jest jednak projektem arystotelesowskim ani klasycznym, lecz ewolucyjnym, zainspirowanym ewolucją ludzkości i odkryciami nauki współczesnej ${ }^{11}$. Jako założenie przyjmuje, że wszyscy ludzie mają tę samą naturę, te same podstawowe potrzeby i wszyscy mają też ten sam cel, jakim jest samorealizacja (2.5351). Jednakże z powodu dzielących ich różnic indywidualnych i kulturowych mogą oni różnie rozumieć

nowożytna, ale również pewna formacja ideowa - nowożytność, nowoczesność lub, jak tu proponuję, moderność. Zob. T. Buksiński, Moderność, Poznań 2001, s. 134-136, Pisma Filozoficzne - UAM w Poznaniu, 77. Buksiński określa neologizm „moderność” jako $w$ pierwszej kolejności, epokę nowożytna, rozpatrywana pod katem tworzenia nowych zjawisk, struktur i procesów; w drugiej - pewne cechy, charakterystyki, struktury, rodzaje zjawisk, uznane wtaśnie za typowe dla spoteczeństw moderności. Hobbes, który radykalnie zerwał z tradycją klasyczną i zbudował swą filozofię polityczną na bazie nowożytnej nauki, podkreślając ludzki egoizm i pragnienie mocy, przyczynił się w sposób istotny do ukształtowania moderności jako formacji ideowej. Kolejną formacją ideową, następującą po moderności, jest postmoderność (ponowoczesność).

Arystoteles, Etyka nikomachejska, przeł. D. Gromska, Warszawa 1982, 1079b, s. 18.

11 Zgodnie z fizyką newtonowską zjawiska fizyczne mają charakter przewidywalny i deterministyczny nie ma tu przypadkowości. Wraz z odkryciem w pierwszej połowie XX w. teorii kwantów okazało się, że na poziomie subatomowym determinizm nie ma już miejsca, a zjawiska mają charakter probabilistyczny. Choć z tą interpretacją, podważającą deterministyczny charakter zjawisk, a także ich obiektywizm, czyli ich niezależność od obserwatora, nie chciało się zgodzić wielu wybitnych fizyków, m.in. Albert Einstein, została ona skrupulatnie potwierdzona doświadczalnie i ostatecznie przeważyła. Wpłynęło to na ukształtowanie się nowego obrazu świata. Zakwestionowane zostały wcześniejsze materialistyczne i deterministyczne interpretacje rzeczywistości fizycznej oraz metoda redukcjonistyczna, które próbowano zastosować także do nauk społecznych. Zob. A. Wendt, Quantum Mind and Social Science. Unifying Physical and Social Ontology, Cambridge 2015. 
własne potrzeby i je indywidualnie modyfikować, w różny sposób też rozumieć szczęście lub samorealizację.

Społeczeństwo to społeczność zróżnicowana. To więc, co niektórzy z nas odbiorą jako sukces, może być porażką dla drugich. Niektórzy ludzie mogą znaleźć spełnienie życiowe, czyli samorealizację, w życiu aktywnym polityka lub przedsiębiorcy, inni w życiu kontemplacyjnym osoby duchownej lub naukowca, inni w prowadzeniu firmy i gromadzeniu majątku, jeszcze inni w niczym się niewyróżniającym życiu codziennym, dostarczającym zwykłych radości i przyjemności. Ponadto, w miarę upływu lat i nabierania nowych doświadczeń, to, co rozumiemy przez samorealizację, może się zmienić. Dlatego nie należy przypisywać mechanicznie tego samego modelu szczęścia albo samorealizacji wszystkim. Szczęśliwe spoteczeństwo jest tym, w którym każdy ma możliwość samorealizacji i szanuje jednocześnie samorealizacje innych (10.03). W szczęśliwym społeczeństwie dążymy do szczęścia, tak jak je sami najlepiej rozumiemy, jednakże bez uzyskiwania go kosztem innych i narzucania go innym. Realizuje się ono w gwarantowanej, dzięki podstawowym prawom i wolnościom, przestrzeni aktywności, w której obywatele mogą się najpełniej rozwijać ${ }^{12}$. Gwarantując tę przestrzeń dla rozwoju osobowościowego jednostki w społeczeństwie, państwo umożliwia naszą samorealizację, w jej aspekcie materialnym, społecznym i duchowym, nie może nam jej jednak nakazać. Jaka ona będzie i kim będziemy w życiu, zależy od naszego indywidualnego wyboru. Z uwagi jednak na to, że jesteśmy istotami rozumnymi i moralnymi, nasza samorealizacja wyraża się najpetniej $w$ doskonatości moralnej i intelektualnej (2.5352).

Doskonalenie się moralne i intelektualne nie może być narzucone ludziom z zewnątrz. Może być jedynie przekazane w procesie edukacji, poparte autorytetem światłych elit, uwewnętrznione i uznane za nasz najwyższy cel. Tylko na wczesnym etapie ewolucji ludzkości moralność mogła być nakazana ludziom przez niezmienne prawa. Jednakże taki odgórny nakaz postępowania według określonych zasad oparty na sankcjach nie przynosi ludziom postępu moralnego. Utwierdza ich jedynie w ograniczonym systemie etycznym. Podobny skutek ma narzucenie ludziom określonego, niezmiennego obrazu świata i niezmiennych zasad rozumowania. Takie narzucenie utrudniłoby im raczej ich rozwój umysłowy, miast go stymulować. Aby rozwijać się intelektualnie i być twórczymi, ludzie muszą odkryć w sobie intelektualną ciekawość, mieć możliwość zmiany swoich wcześniejszych poglądów oraz posiadać zdolność oraz uprawnienie do swobodnego formułowania i wyrażania swoich myśli. O ile więc dyscyplina zewnętrzna może być konieczna na pewnym etapie rozwoju, zarówno indywidualnego, jak i społecznego, o tyle na późniejszych etapach rozwój moralności i rozumności muszą stać się wewnętrznymi procesami. Ta wewnętrzność wyraża się w rozkwicie cnót moralnych i intelektualnych, zwłaszcza w miłości i mądrości. Jak to

12 O możliwości samodoskonalenia mówi nie tylko tradycja klasyczna, ale nawet klasyczny liberalizm. W koncepcji wolności osadzonej w klasycznej liberalnej myśli politycznej sfera indywidualnej wolności rozszerza się na skutek samodoskonalenia jednostki, a nie na skutek zabezpieczenia jej przez państwo, co akcentuje liberalna myśl współczesna. Zob. Z. Rau, Zapomniana wolność. W poszukiwaniu historycznych podstaw liberalizmu, przeł. M. Przychodzień, Warszawa 2008, s. 78. 
pięknie wyraził Stefan Swieżawski: $w$ sferze poznawczej nie rozumowanie, lecz ogląd kontemplacyjny i zdolność sądzenia - a więc bardziej mądrość niz wiedza - powinny być uznane za najwyższq wartość; a w sferze postępowania mitość jako praktyczny regulator i motor wszystkich stosunków międzyludzkich. W tym świetle prawdziwie kulturalnym jest cztowiek madry i umiejacy kochać13.

Wyrazem rozwoju kultury i cywilizacji są wartości, a zwłaszcza te najwyższe, jakimi są mądrość i miłość. Kiedy ludzie stają się szlachetni, odczuwają radość wewnętrzną z wykonywania rzeczy, które są moralnie prawe; kiedy stają się inteligentni, znajdują radość wewnętrzną w odkrywaniu nowych rzeczy i poszerzaniu swojej wiedzy. O takich, szlachetnych i uczonych, można powiedzieć, że stanowią elitę we właściwym słowa tego znaczeniu. Jej istnienie jest nieodzowne dla szczęśliwego społeczeństwa. Cnoty, takie jak: uczciwość, pracowitość, odwaga, mądrość, miłość, jakie sobą reprezentują, budują współdziałanie. Dlatego też każde społeczeństwo, nawet demokratyczne, aby było szczęśliwe, musi zawierać szlachetny element. Dobra demokracja to sofokracja, czyli uszlachetniona demokracja (6). Musi być oparta na cnotach. Jeśli w polityce brakuje cnót, szczególnie uczciwości, ulega ona korupcji. Traci podstawowy charakter dobrego rządzenia i staje się zwykłą grą różnych interesów partykularnych. Jest zdominowana przez grupy nacisku i obecność osób przeciętnych, które uzurpują władzę, ponieważ brakuje im kwalifikacji moralnych i intelektualnych. Życie społeczne staje się wówczas coraz bardziej niepewne co do przyszłości, rozdarte konfliktami, manipulowane przez media, zmaterializowane; nie ma już w nim miejsca dla dobrej literatury, sztuk pięknych oraz głębszej zadumy filozoficznej i religijnej.

O ile życie biologiczne człowieka podlega prawom o charakterze deterministycznym, życie społeczne nie jest mechanizmem, lecz podlega prawom wolności, które sami tworzymy. Są to zasady skutecznego działania, które wynikają z naszych naturalnych potrzeb, przynoszą korzyść jednostce i grupie i nie są związane z krzywdzeniem innych ludzi. Prawa te traktują społeczeństwo jako organizm i rozwijają je w nawiązaniu do tradycji i doświadczeń pokoleń. Podstawową różnicą między maszyną lub mechanizmem a organizmem jest to, że maszyny są skonstruowane i kontrolowane, a organizmy tworzą się spontanicznie i same rosną. Nadal wpływające na nasze myślenie poglądy na temat mechanicznej organizacji społeczeństwa i państwa mają źródło w koncepcji kontraktu społecznego Hobbesa i Locke'a. Po to, aby do zjawisk społecznych móc zastosować prawa podobne do tych, które rządzą światem fizycznym, dla opisu tych zjawisk przyjęli oni mechaniczny obraz cztowieka poruszanego przez pożadania (2.554). Ale taki obraz nie jest adekwatny do natury człowieka. Nie można sprowadzić nas, ludzi, do jednego wymiaru, jakim jest pożądanie, wola mocy czy interes własny. Jesteśmy istotami zbyt złożonymi, aby mogły nas opisać mechaniczne prawa wzorowane na prawach fizyki newtonowskiej. Tylko w niektórych cywilizacjach, a mianowicie tych, które nie wykraczają poza pierwszy etap ewolucji ${ }^{14}$ lub do niego się degradują, występuje mechanizacja

13 S. Swieżawski, Cztowiek i tajemnica, Kraków 1978, s. 132.

14 Jedną z najbardziej wzniosłych idei filozoficznych jest ewolucja ludzkości. Odnajdziemy ją w książkach Herberta Spencera, Teilharda de Chardin, Juliana Huxleya i innych myślicieli. Warto też przypomnieć 
ludzkich zachowań za pomocą aparatu przymusu. Przykładem takiej cywilizacji jest cywilizacja orientalno-bizantyjska, która stopniowo eliminuje wolnośćprzez swoją wszechpotężna biurokrację (5.43). Aby ożywić naszą cywilizację zachodnią, musimy odkryć ponownie tradycję klasyczną ${ }^{15}$, czyli nasze odwieczne dziedzictwo klasyczne. Innymi słowy, musimy uwolnić się od myślenia w kategoriach dominacji, centralizmu, standaryzacji i jednolitości i odnaleźć wolność, autonomię, samorządność i różnorodność. Nasze relacje musimy oprzeć na współdziałaniu. Ten kierunek sugeruje nam nauka współczesna.

Pierwszą zasadą ludzkości jest współdziałanie. Możemy sobie wyobrazić, że nie mamy ze sobą kontaktu albo że jesteśmy odseparowywanymi od siebie jednostkami lub mieszkamy w odgrodzonych od siebie krajach, ale wówczas, zdani wyłącznie na siebie, niewiele byśmy osiągnęli i pewnie szybko umarlibyśmy śmiercią naturalną. Społeczeństwo to społeczność zróżnicowana, połączona więzami współdziałania. Składa się z ludzi, którzy różnią się od siebie poziomem bogactwa, inteligencji i wykształcenia, a także nawykami i cechami charakteru. Wszyscy muszą wspólnie pracować, aby zrealizować indywidualne i wspólne cele. Pomysł usunięcia wszystkich różnic między ludźmi, uczynienia ich wszystkich takimi samymi i stworzenia w ten sposób społeczeństwa bezklasowego nie jest zgodny z naturą ludzką ani też nie sprzyja postępowemu rozwojowi ludzkości. Każda klasa społeczna czy specyficzna grupa społeczna, czy określona społeczność reprezentuje pewne wartości i to stanowi jej potencjalny wkład do wspólnoty. To od niej, od jej rzeczywistego wkładu i wartości, jakie sobą reprezentuje, zależy, czy będzie kooperatywna czy pasożytnicza. Zamiast więc dążyć do tego, aby ujednolicić ludzi i ich kultury i doprowadzić społeczeństwa do standaryzacji, uznajemy unikalne różnice między nimi i uczymy się współpracy. Tworząc prawa wolności, czyli reguły postępowania, które przynoszą wspólny sukces w działaniu, kształtujemy w sposób pozytywny naszą rzeczywistość - nasz świat.

Największe osiągnięcia w dziedzinie odkryć naukowych, twórczości artystycznej, działalności gospodarczej i przywództwa politycznego ludzkość zawdzięcza wysoko uzdolnionym, wybitnym osobom. Dlatego zamiast przykładać zbyt wielką wagę

teorię ewolucji Józefa Hoene-Wrońskiego, swą myślą wybiegł on bowiem na wiele lat wprzód i jego idee, choć wyrażone językiem już dziś nieco archaicznym, a zarazem hermetycznym i trudnym do zrozumienia, wydają się nadal aktualne. Na pierwszym etapie ewolucji ludzkości, który można określić jako początek historii, ludzkość wyłania się więc ze stanu zwierzęcości lub prymitywizmu. Na etapie, który określić można jako samorzutność prawna człowieka, kształtuje się wczesna kultura, wykształcają się obyczaje i prawo zwyczajowe, a wraz z rozwojem pierwszych cywilizacji powstają wielkie kodeksy prawne. Zob. J. Hoene-Wroński, Metapolityka, przeł. J. Jankowski, Warszawa 1923, Prace Instytutu Mesjanistycznego w Warszawie. Koncepcję ewolucji ludzkiej Hoene-Wroński przedstawił w Metapolityce, a także w książce Prodrom do Mesjanizmu i innych wcześniejszych pracach; koncepcja przedstawiona w Metapolityce wydaje się najpełniejsza.

15 Tradycja klasyczna to tradycja moralna, która wyłoniła się w europejskiej myśli politycznej. Obejmuje myślicieli, dla których polityka jest nieodłącznie związana z etyką i którzy podkreślają wagę cnót w życiu publicznym. Ukształtowali ją Platon, Arystoteles, Cyceron i inni wielcy filozofowie starożytności. Kontynuowana była przez filozofów chrześcijańskich - św. Augustyna i św. Tomasza z Akwinu. Zob. W.J. Korab-Karpowicz, Historia filozofii politycznej. Od Tukidydesa do Locke'a. Tradycja klasyczna i jej krytycy, Kęty 2010, s. 344-346, Daimonion. 
do równości między ludźmi, dostrzegajmy potrzebę jakości i indywidualności. Starajmy się podnosić ogólną jakość życia, a zarazem doceniać osoby ponadprzeciętne. Nasze zdolności i osobowości stanowią najważniejsze zasoby świata. Decydują one o naszej twórczości, bez której nie ma rozwoju ludzkości. Musimy więc współpracować, ale jednocześnie zachować naszą twórczą różnorodność. Dotyczy to nie tylko różnorodności wynikającej z różnych wartości reprezentowanych przez jednostki i grupy wewnątrz społeczeństw i ich potencjalnego wkładu do wspólnoty, lecz także różnorodności państw i tworzących je społeczeństw. Nie należy ich zastępować przez państwo światowe lub inną organizację prowadzącą do ujednolicenia ludzkości i umożliwiającą łatwe nią sterowanie. Państwa powinny zachować rozmaitość, a jednocześnie współpracować w ramach wspólnoty międzynarodowej. Siedem zasad politycznego racjonalizmu przedstawionych w Traktacie polityczno-filozoficznym wyraża nową wizję polityki zagranicznej. Jej kwintesencją jest nasze wspólne zadanie, jakim jest budowanie silnej spoteczności międzynarodowej, opartej o wspólne wartości, szacunek dla prawa międzynarodowego i wspótdziatanie dla dobrobytu i postępu catej ludzkości (9.51).

Wraz z rozwojem nauki ludzkość nabiera potęgi. Jest to potęga potrzebna dla naszej dalszej ewolucji mającej obecnie charakter kulturowy. Ale ta wielka i ciągle wzrastająca potęga może też być użyta do zniszczenia. Dysponujemy już obecnie mocą, która pozwala w ciągu kilku godzin zniszczyć całe życie naszej planety. Zbliżyliśmy się do decydującego momentu w dziejach ludzkości. Dalsza ewolucja ludzka, która jest jednocześnie kolejnym etapem ewolucji wszechświata, nie może posunąć się naprzód, dopóki nasz rozwój moralny nie zrówna się z intelektualnym. W procesie ewolucyjnym, w jego fazie kulturowej lub ludzkiej, opartej na wolności, jest możliwość postępu, ale też regresu. Możemy współdziałać ze sobą i świadomie kontynuować proces ewolucji, ale możemy też ulec demoralizacji, trwać w niekończących się sporach i walce o władzę albo, motywowani wzajemną nieufnością lub wolą dominacji, siebie wzajemnie niszczyć. Wielu ludzi myśli nadal tak, jak gdyby należeli do pierwszego etapu ludzkiego rozwoju. Chcą panować nad innymi. Snują plany dominacji politycznej, gospodarczej, finansowej, kulturowej lub religijnej. Ale to, co było wcześniej możliwe, nie jest już możliwe teraz. Wojna światowa oznaczała kiedyś śmierć i cierpienie milionów ludzi, dzisiaj, z uwagi na możliwość zastosowania broni masowego rażenia, oznacza unicestwienie ludzkości, a w najlepszym wypadku, kiedy część ludzi przeżyje, głęboki upadek cywilizacyjny. Abyśmy mogli więc pójść dalej ścieżką ewolucji i w pełni móc korzystać z coraz większych możliwości oraz wolności, jaką daje nam nauka i technika, musimy uświadomić sobie własną sytuację i dokonać decydującej transformacji: od woli dominacji i podboju do woli doskonałości i współdziałania. Współdziałanie prowadzi do harmonii w relacjach międzyludzkich. Aby ją zrealizować, musimy odnaleźć zgodność między wielkim rytmem życia powszechnego [a więc harmonią wszechświata] i rytmem duszy ludzkiej [harmonią w nas samych] ${ }^{16}$.

16 M.C. Ghyka, Ztota liczba. Rytuaty i rytmy pitagorejskie w rozwoju cywilizacji zachodniej, przeł. I. Kania, Warszawa 2006/2014, s. 215. 
Za cel ludzkiego życia można uznać dążenie do doskonałości, zarówno moralnej, jak i intelektualnej, pełne wyzwolenie ukrytych w nas różnorodnych talentów. Innymi słowy, naszym celem jest samodoskonalenie. To samodoskonalenie, albo samoprzekształcanie się ludzkości, czyli ciągłe przekraczanie własnych granic, jest widoczne w postępie naukowo-technicznym, za którym na tym etapie naszej ewolucji nie nadąża jednak postęp etyczny. To jest to brakujące ogniwo w procesie rozwoju ludzkości. Dla dalszego przekształcenia potrzebujemy więc zrozumieć wagę naszego moralnego doskonalenia się oraz wejść na drogę ogólnoludzkiej współpracy. Tego wymaga od nas ewolucja ludzkości i oparta na niej nowa polityka jako sztuka rządzenia.

\section{BIBLIOGRAFIA}

Arystoteles, Etyka nikomachejska, przel. D. Gromska, Warszawa 1982.

Buksiński T., Moderność, Poznań 2001, Pisma Filozoficzne - UAM w Poznaniu, 77.

Czaputowicz J., Suwerenność, Warszawa 2013.

Ghyka M.C., Ztota liczba. Rytuaty i rytmy pitagorejskie w rozwoju cywilizacji zachodniej, przeł. I. Kania, Warszawa 2006/2014.

Hobbes T., Lewiatan czyli Materia, forma i wtadza państwa kościelnego i świeckiego, przeł. Cz. Znamierowski, wstęp J.C.A. Gaskin, Warszawa 2005.

Hoene-Wroński J., Metapolityka, przeł. J. Jankowski, Warszawa 1923, Prace Instytutu Mesjanistycznego $w$ Warszawie.

Korab-Karpowicz W.J., Umowa czy harmonia spoteczna, „Societas et Ius” 2015, nr 4, [online] http://dx.doi.org/10.12775/SEI.2015.001.

Korab-Karpowicz W.J., Historia filozofii politycznej. Od Tukidydesa do Locke'a. Tradycja klasyczna i jej krytycy, Kęty 2010, Daimonion.

Korab-Karpowicz W.J., Tractatus Politico-Philosophicus. New Directions for the Future Development of Humankind, New York 2017, Routledge Focus.

Korab-Karpowicz W.J., Tractatus politico-philosophicus. Traktat polityczno-filozoficzny, Kęty 2015, Biblioteka Europejska.

Lamentowicz W., Strategia państwa. Teoria państwa aktywnego wobec sit spontanicznych, Warszawa 2015.

Lutosławski W., Praca narodowa, Warszawa 1998, Mata Klasyka Filozofii.

Morgenthau H., Politics among Nations. The Struggle for Power and Peace, wyd. 2, New York 1956.

Morgenthau H., Polityka między narodami. Walka opotegę ipokój, przejrzał i uzup. K.W. Thompson, przeł. R. Włoch, Warszawa 2010.

Rau Z., Zapomniana wolność. Wposzukiwaniu historycznych podstaw liberalizmu, przeł. M. Przychodzień, Warszawa 2008.

Swieżawski S., Cztowiek i tajemnica, Kraków 1978.

Wendt A., Quantum Mind and Social Science. Unifying Physical and Social Ontology, Cambridge 2015. 
Dr hab. W. Julian KORAB-KARPOWICZ - profesor Uniwersytetu Zayed w Dubaju i Uczelni Łazarskiego w Warszawie. Doktor Uniwersytetu Oksfordzkiego w Oksfordzie, doktor habilitowany Uniwersytetu im. Adama Mickiewicza w Poznaniu. Były wiceprezydent Gdańska i ekspert Komisji Europejskiej. Wykładał na wielu uczelniach zagranicznych na trzech kontynentach, w tym na Anglo-Amerykańskim Uniwersytecie w Pradze i Stanowym Uniwersytecie Teksasu. Członek zagranicznych towarzystw naukowych, m.in. American Philosophical Association, World Philosophical Forum, Indian Philosophical Congress oraz International Political Science Association. Autor wielu prac z zakresu filozofii i myśli politycznej, w większości opublikowanych w USA i Wielkiej Brytanii. Ostatnio ukazaly się The Presocratics in the Thought of Martin Heidegger (2016), On the History of Political Philosophy. Great Political Thinkers from Thucydides to Locke (2016) i Tractatus Politico-Philosophicus. New Directions for the Future Development of Humankind (2017). W przygotowaniu do druku jest książka Harmonia spoteczna, czyli zasady szczęśliwego spoteczeństwa. 